\title{
EVOLUTION OF THE PRODUCTION AND PRICE OF FOREST BIOMASS FOR ENERGY
}

\author{
Thiago Manoel Sozinho dos Santos ${ }^{1 *}$, David Alexandre Buratto ${ }^{1}$, Anadalvo Juazeiro dos Santos ${ }^{2}$, João Carlos \\ Garzel Leodoro da Silva ${ }^{2}$, José Roberto Frega ${ }^{3}$ \\ ${ }^{1}$ Federal University of Paraná, Program in Forest Engineering, Curitiba, Paraná, Brazil - thiago_sozinho@hotmail.com*; \\ davidburatto@yahoo.com.br \\ ${ }^{2}$ Federal University of Paraná, Department of Economics and Rural Extension, Curitiba, Paraná, Brazil - ajsantos.ufpr@gmail.com.br; \\ garzel@icloud.br \\ ${ }^{3}$ Federal University of Paraná, Department of General and Applied Administration, Curitiba, Paraná, Brazil - jose.frega@gmail.br
}

Received for publication: 04/04/2017 - Accepted for publication: 08/06/2018

\begin{abstract}
This study aimed to analyze the evolution of the production and price of biomass from native and planted forests of the state of Paraná (Brazil), between 1998 and 2015, based on the behavior of the prices of the products, according to variations of their supply or demand. The annual rates for growth of the price and quantity produced were calculated and related to the displacements of the supply and demand curves of the products. The results indicated a decrease in the quantity and an increase in the biomass price for native forests, which caused a shift in the supply curve to the left. For the biomass of planted forests, the demand curve shifted to the right due to the demand increase of this product for energy production. The behavior of both curves indicated a substitution of the biomass from native forests to biomass from planted forests due to factors related to the increase of environmental protection regarding the native forests located in the state of Paraná.

Keywords: Forest biomass market, bioenergy consumption, forest product.
\end{abstract}

\section{Resumo}

Evolução da produção e preço da biomassa florestal para energia. O presente estudo teve por objetivo analisar a evolução da produção e preço da biomassa de florestas nativas e plantadas do estado do Paraná durante o período de 1998 a 2015, através do comportamento dos preços dos produtos, de acordo com as variações de sua oferta ou demanda. As taxas anuais de crescimento do preço e quantidade produzida foram calculadas e relacionadas com os deslocamentos das curvas de oferta e demanda dos produtos. Os resultados obtidos indicaram que houve uma diminuição na quantidade e aumento do preço da biomassa de florestas nativas, provocando um deslocamento da curva de oferta do produto para a esquerda, enquanto que, para a biomassa de florestas plantadas, a curva de demanda se deslocou para a direita, em razão do aumento de sua demanda para a produção de energia. Os comportamentos das duas curvas indicaram uma substituição da biomassa de florestas nativas pela biomassa de florestas plantadas em razão de fatores relacionados ao aumento da proteção ambiental das florestas nativas localizadas no estado do Paraná.

Palavras-chave: Mercado de biomassa florestal, bioenergia, produto florestal.

\section{INTRODUCTION}

Considered to be the most important energy source in poor countries because it is relatively less expensive compared to other sources, forest biomass from renewable raw materials plays a prominent role in the world economy, accounting for more than half of the energy supply in some countries (INTERNATIONAL ENERGY AGENCY - IEA, 2013).

Wood, especially firewood, is one of the main renewable raw materials for power generation. In 2015, it contributed $8.2 \%$ to primary energy production. In addition, it occupies the 5th place in the Brazilian energy matrix, behind oil, sugarcane bagasse, hydraulic energy and natural gas (EMPRESA DE PESQUISA ENERGÉTICA - EPE, 2016). In the state of Paraná, based on the information available in the 2010 Paraná State Balance Sheet, produced by Companhia Paranaense de Energia (COPEL), the share of forest biomass accounted for approximately $11.2 \%$ of the state energy matrix in the year of 2009 .

This source of energy is obtained through the exploitation of natural forests or high yield plantations. In Brazil, the main origin comes from the exploitation of natural forests. However, more recently, consumption has been supplied by the exploitation of planted forests, especially of fast-growing forest species such as Eucalyptus sp., Pinus sp. and Mimosa (Bracatinga), the latter having a major occurrence in the Southern Region of Brazil (BRAND et al., 2014). According to EPE (2016), forest biomass plays an important role in the regional

FLORESTA, Curitiba, PR, v. 49, n. 1, p. 011-020, jan/mar. 2019

Santos. T. M. S et.al.

ISSN eletrônico 1982-4688

DOI: $10.5380 /$ rf.v49i1.51617 
economy of Paraná. It is used as one of the main sources of energy for combustion or direct burning and is the most traditional form of energy use obtained from this raw material. Among its main uses in the state of Paraná, stands out: for agricultural use, drying grains, providing thermal comfort for animals and rural breeding, among others; for industrial use, heating and steaming generation in industrial plants; for residential use, generating heat to meet human comfort, food preparation, among others; and commercial use, such as in bakeries, restaurants, among others.

The demand for forest biomass in Paraná in 2009 was approximately 14.9 million cubic meters of wood. The agricultural sector together with the beverage and food sectors consumed, in the same period, 6.3 million cubic meters of wood (42\%) (COPEL, 2010). Therefore, due to the relevance of this consumption to the economy of the state of Paraná, the constant monitoring of the economic data of the forest biomass market in the state is a strategic information for the planning of the agricultural and forestry sector at regional level, specifically for producers and consumers of native and planted forest biomass.

In this context, the present study aimed to analyze the evolution of the production and the price of natural and planted forest biomass between 1998 and 2015, through the behavior of the product price according to the variations of supply and demand during this period.

\section{MATERIAL AND METHODS}

The present study followed the model proposed by Almeida et al. (2009), with estimation of trend models that calculated the annual growth rates of the price and quantity of native forest biomass produced in Paraná during the period, and the identification of the displacements of the supply and demand curves of native and planted forest biomass based on the results achieved. In addition, the proposal of Almeida et al. (2008) and considering that the firewood market in Paraná operates in a structure of relative competition, that the elasticities of the demand and supply price are not completely elastic or inelastic (vertical or horizontal inclination) and that the market agents act in a rational way. The econometric models were validated by statistical assumptions.

\section{Material}

Data were collected from the Brazilian Institute of Geography and Statistics (IBGE) (2016), from the Production of Plant Extraction and Silviculture (PEVS) database referring to Paraná. The quantity produced in cubic meter $\left(\mathrm{m}^{3}\right)$ and the value of forest biomass production from extractive (native forest biomass) and planted forests (planted forest biomass) were the information collected per year between 1998 and 2015. This period of analysis was based on the premise of obtaining the largest set of time series of the same size, since the same number of observations was required for all the series of analysis performed.

The production value series was corrected by the Broad Consumer Price Index (IPCA), based on the average index of 2015, as used by Almeida et al. (2009a), Almeida et al. (2009b) and Moreira et al. (2016).

The price was obtained according to the equation used by Almeida et al. (2009a), which suggests the use of the ratio between the production value $(\mathrm{R} \$)$ and the amount of native and planted forest biomass produced (Equation 1).

$$
P=\frac{V P}{Q P}
$$

In which: P: price $\left(\mathrm{R} \$ / \mathrm{m}^{3}\right)$; VP: native and planted forest biomass production value $(\mathrm{R} \$)$; and $\mathrm{QP}$ : amount of native and planted forest biomass produced $\left(\mathrm{m}^{3}\right)$.

\section{Methods}

Substitute good determination

As previously stated, forest biomass is a bio energy source used by many countries to serve their sectors of the economy and society. However, with the existing pressure to maintain natural ecosystems, particularly for tropical forests, the existence of forest crops for energy purposes is becoming more common. (TETTO et al., 2008)

For this study, it was considered that the increase of biomass consumption from planted forests would tend to reduce the biomass utilization of native forests. For this, we applied the Elasticity-Price cross-demand $\left(E_{p}\right)$, suggested by Mankiw (2015) and described in Equation 2.

$$
E_{p}=\frac{\frac{\Delta Q}{Q_{i}}}{\frac{\mu_{F}}{P_{i}}}
$$


In which: $\mathrm{E}_{\mathrm{p}}$ : Elasticity-Price cross-demand; $\Delta \mathrm{Q}$ : change in the quantity demanded of a $j$ product at final time $f$ $\left(Q_{f}\right)$ and initial time $i\left(Q_{i}\right)$; and $\Delta \mathrm{P}$ : substitute product $k$ price variation at final time $\mathrm{f}\left(P_{f}\right)$ and initial time $i\left(P_{i}\right)$.

According to Pindick and Rubinfeld (2011), for positive results (EP > 0), the product is considered a substitute. For negative results (EP < 0), the product is considered complementary. Gujarati and Porter (2011) mention that it is necessary to verify the structure break to maintain the period regressions statistically identical. In this way, it was possible to verify if the planted forest biomass behaved or not as a substitute or complementary product of the native forest biomass in the short term of three years.

For this, the time series of native forest biomass and the price of planted forest biomass were divided in periods when there was a structural break: 1998-2000, 2001-2003, 2004-2009, 2010-2012, and 2013-2015. This division was based on the Chow Test, which verifies if the parameters are stable throughout the period and performed through the Gretl 2016d-git ${ }^{\circledR}$ computational application. This test was based on the p-value results obtained. In this case, according to Gujarati and Porter (2011), the p-value was considered and, for values below 0.05 , the null hypothesis $\left(\mathrm{H}_{0}\right)$ was rejected and the periods were separated;and for values above 0.05 , the null hypothesis was not rejected, the data sub-periods were joined and used to estimate a single equation.

\section{Estimation of growth rates}

The first stage consisted in the estimation of the annual growth rates of the price and quantity of native and planted forest biomass produced in Paraná. According to Gujarati and Porter (2011), the process for obtaining growth rates can be performed according to Equation 3.

$$
Y_{\mathrm{t}}=Y_{0}(1+r)^{T}
$$

In which: $\mathrm{Y}_{\mathrm{t}}$ : price $\left(\mathrm{P}_{\mathrm{t}}\right)$ or quantity $\left(\mathrm{Q}_{\mathrm{t}}\right)$ of native and planted forest biomass, considering the $r$ rate, over time $T$; $\mathrm{Y}_{0}$ : initial price or quantity; r: compound capitalization rate; and $\mathrm{T}$ : period.

To estimate the growth rate, Gujarati and Porter (2011) recommend transforming the variables from Equation 3 into a natural logarithm to describe Equation 4. Adding the error term $\varepsilon_{t}$ to Equation 3, we obtain the regression model expressed by Equation 5, which presents the intercept $\left(\beta_{1}\right)$ and the slope coefficient $\left(\beta_{2}\right)$.

$$
\begin{aligned}
& \ln Y_{\mathrm{t}}=\ln Y_{0}+T \ln (1+r) \\
& \ln Y_{\mathrm{t}}=\beta_{1}+\beta_{2} T+e_{\mathrm{t}}
\end{aligned}
$$

In which: $\beta_{1}=\ln Y_{0}$; and $\beta_{2}=\ln (1+r)$.

Also, following the calculation methodology proposed by Gujarati and Porter (2011), the first parameter measures the average annual quantity or price (regardless of time) and the second parameter measures the constant proportional variation in $Y$ (price or quantity) for a given absolute change in the regressor, in this case, the variable $T$. The composite growth rate can be obtained by using Equation 6 .

$$
r=\left(e^{\beta_{2}}-1\right) \times 100
$$

In which: $e$ : antilog.

For a better visualization of the growth rates of the quantity produced and the price, their evolutions and respective linear trends were presented graphically.

Model estimation and validation

The model was estimated by the Ordinary Least Squares (OLS) method, and the quality of fit was determined according to the significance levels of $1 \%, 5 \%$ and $10 \%$. However, this does not guarantee statistical safety. Therefore, it is necessary to validate the model based on the assumptions of a classical linear regression model through heteroskedasticity tests, normality of errors, specification (adequacy of the functional form) and serial correlation (autocorrelation). However, the application of the tests can only be performed after the detection of outliers and the verification of stationarity of the variables, as proposed by Gujarati and Porter (2011) and used by Almeida et al. (2008).

The variables used were: the amount of forest biomass produced in Paraná (in $\mathrm{m}^{3}$ ) and the price of forest biomass marketed in Paraná (in $\mathrm{R} \$ / \mathrm{m}^{3}$ ). These variables were necessary to determine the behavior of supply and demand of native and planted forest biomass in the state (ALMEIDA et al., 2009a). 
This study investigated atypical values (outliers) by means of the Mahalanobis Distance $\left(\mathrm{D}_{\mathrm{M}}\right)$, in which the observation is an outlier if the result of the $\mathrm{D}_{\mathrm{M}}$ probability for each observation is below 0.001, according to Tabachnick et al. (2001). The calculation of this probability is given by the difference between one and the chi-square Accumulated Distribution Function (ADF), considering the $\mathrm{D}_{\mathrm{M}}$ result and the number of degrees of freedom (two).

The KPSS absence test of unit root was used to verify if the variables have seasonal behavior. Gujarati and Porter (2011), recommend that if the variables do not have this behavior in their original state, they should be transformed into "first differences of variables" or "logarithmic differences of variables". The hypotheses of this test were: $\mathrm{H}_{0}$ for absence of unit root (stationary); and $\mathrm{H}_{1}$ for presence of unit root (non-stationary).

Regarding the assumptions of the classical linear regression model, the White test was performed to verify the heteroscedasticity (if the regression errors had different variances). The hypotheses of the test were: $\mathrm{H}_{0}$ if the variance of the residues were homocedastic; and $\mathrm{H}_{1}$ if the variance of the residues were heteroskedastic (GUJARATI; PORTER, 2011).

The specification of the model, that is, the adequacy of the included variables, was tested by the Ramsey Reset. The hypotheses of the test were: $\mathrm{H}_{0}$ for correct model specification; and $\mathrm{H}_{1}$ for incorrect specification of the model. Normality in the distribution of residues was verified by the Doornik-Hansen test. The hypotheses of this test were: $\mathrm{H}_{0}$ if the error had normal distribution; and $\mathrm{H}_{1}$ if the error did not have normal distribution (GUJARATI; PORTER, 2011).

Finally, the Durbin-Watson $d$ test checked whether there was independence of the observations errors over time, that is, if there was no serial correlation. If the result was close to two, the test indicated absence. However, GLS, in substitution for the OLS, was applied by means of the first order auto regressive model AR (1), since, through this method, the result of the test tends to be closer to two due to its internal robustness. Thus, the model becomes better adjusted. The detection of outliers was performed with the software IBM $^{\circledR}$ SPSS $^{\circledR} 21$, while for the verification of stationarity and the assumptions of the classical linear model, the GRETL ${ }^{\circledR} 2016 \mathrm{c}$ was used.

Behavior of supply and demand curves

Based on the signs of the growth rates calculated in the first stage, the second stage started, which consisted in determining the behavior of the biomass market of native and planted forest. According to Almeida et al. (2008), the attainment of a positive growth rate for price and quantity suggests a shift of the demand curve to the right, being greater than any supply displacement, either to the left or the right. If growth rates are negative for the same variables, we suggest a demand shift to the left.

According to Pindyck and Rubinfeld (2011), with regard to supply, a shift to the right greater than any shift of demand, whether left or right, implies in an increase in quantity produced and a decrease in price. In the case of a dominant shift of supply to the left, we get an increase in price and a decrease in quantity (Table 1).

Table 1. Supply behavior and demand curves according to the variation of the growth rates of the price and quantity of native and planted forests biomass .

Tabela 1. Comportamento das curvas de oferta e demanda conforme variação das taxas de crescimento do preço e quantidade de biomassa de florestas nativas e plantadas.

\begin{tabular}{l|l|l}
\hline $\begin{array}{l}\text { Type of variation of quantity and price } \\
\text { growth rate }\end{array}$ & $\begin{array}{l}\text { Type of } \\
\text { framework }\end{array}$ & Variation in supply and demand curves \\
\hline Positive variation in quantity and price & $\uparrow \mathrm{D}$ & Dominant shift of Demand to the right \\
\hline $\begin{array}{l}\text { Negative variation in quantity and price } \\
\text { nositive variation in quantity and }\end{array}$ & $\downarrow \mathrm{D}$ & Dominant shift of Demand to the left \\
\hline $\begin{array}{l}\text { Negative variation in quantity and } \\
\text { positive variation in price }\end{array}$ & $\downarrow S$ & Dominant shift of Supply to the right \\
\hline
\end{tabular}

Source: Almeida et al. (2009a).

\section{RESULTS}

\section{Statistical analysis of time series}

The historical series of quantity produced and the price of biomass originating from native forests and planted forests (in this study, native forest biomass and planted forest biomass, respectively) indicated the nonoccurrence of atypical values through the probability of $\mathrm{D}_{\mathrm{M}}$, already that the results were greater than 0.001 . 
Regarding stationarity, the KPSS test pointed to the occurrence of seasonal behavior of the time series of biomass variables of native and planted forest. The result of the White test indicated the acceptance of the null hypothesis, noting that the residue variance was homoscedastic for the variables of both products. The specification of the model is suitable for accepting the null hypothesis of the Ramsey Reset test.

The Doornik-Hansen test of errors normality pointed out the non-acceptance of the null hypothesis for the model, indicating that the errors were not normally distributed within the variables of the two products. However, when the Durbin-Watson $d$ test was applied to verify the serial correlation of the model, values farther apart were recorded (2.966238 to the price of native forest biomass and 1.49301 tothe amount of native forest biomass), indicating the existence of an auto correlation problem. Therefore, the GLS was applied by means of the first order auto regressive model AR (1), which presented a result closer to two $(2.158693$ for the price of native forest biomass, and 1.702735 for the amount of native forest biomass). Regarding planted forest biomass, the OLS was efficient to detect the occurrence of auto correlation for price (1.821208) and quantity (2.099151).

\section{Growth rates and behavior of the quantity and price curves of native and planted forest biomass}

The production of biomass of native forest in the state of Paraná decreased to an annual rate of $7.7 \%$ between 1998 and 2015, while the price of $\mathrm{m}^{3}$ increased by $6.8 \%$ per year (Figure 1).

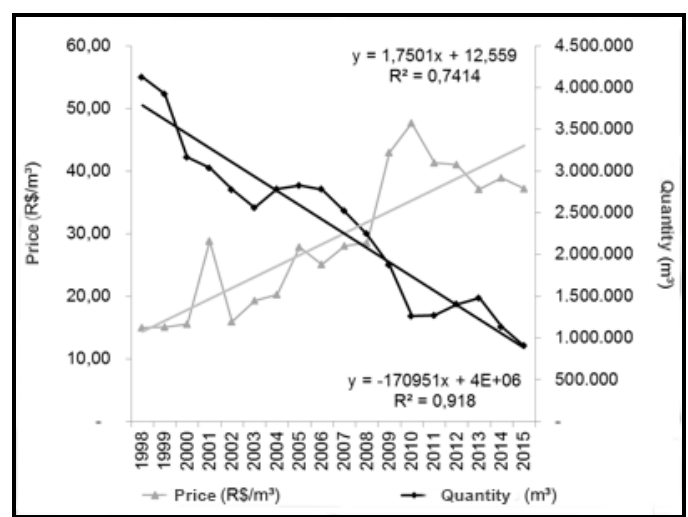

Figure 1. Price and quantity evolution of native biomass and its linear growth trends for the period from 1998 to 2015.

Figura 1. Evolução do preço e da quantidade produzida de biomassa de floresta nativa e suas tendências lineares de crescimento no período de 1998 a 2015.

Between 1998 and 2011 there was a positive annual increase in quantity (9.1\%) as well as in the price of the product $(6.1 \%)$ for planted forest biomass. However, as of 2012, there was oscillating behavior of the two variables (Figure 2).

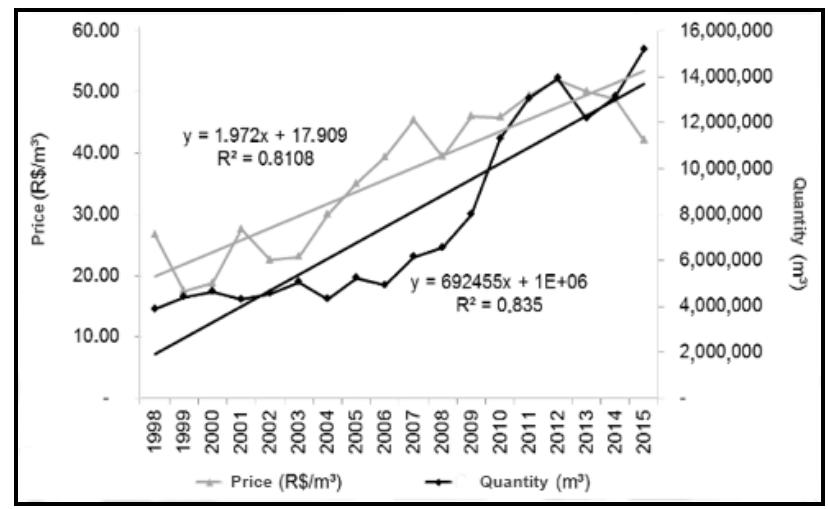

Figure 2. Price and quantity evolution of planted biomass and its linear growth trends for the period from 1998 to 2015.

Figura 2. Evolução do preço e da quantidade produzida de biomassa de floresta plantada e suas tendências lineares de crescimento no período de 1998 a 2015. 


\section{Substitute good determination}

The results shown by the application of $E_{p}$ revealed that, in the majority of subperiods, planted biomass was a substitute product of native forest biomass (Table 2).

Table 2. Elasticity-Price of the cross-demand between the amount of native forest biomass and the price of planted forest biomass for each period.

Tabela 2. Elasticidade-Preço da demanda cruzada entre a quantidade de biomassa de floresta nativa e o preço da biomassa de floresta plantada em cada período.

\begin{tabular}{ll}
\hline Periods & $E_{p}$ \\
\hline $1998-2000$ & 0.79 \\
$2001-2003$ & 0.96 \\
$2004-2009$ & -0.61 \\
$2010-2012$ & 0.84 \\
$2013-2015$ & 2.44 \\
\hline
\end{tabular}

In the first two $(1998$ - 2000) and in the last two subperiods (2013 - 2015), it was observed that the results were positive, indicating that the planted forest biomass behaved as a substitute product of native forest biomass. The negative result between 2004 and 2009 (-0.61) indicates that the products were complementary in this period. This is due to the fact that the period from 2004 to 2009 had an effect caused by the decrease in the production of forest plantations in previous years, as pointed out in the SETI report (PARANÁ, 2007). According to Almeida et al. (2009b), the effect caused by a possible forest blackout in the state of Paraná encouraged new plantations of forest species with the sectors intention of preventing a possible shortage of wood.

\section{Behavior of supply and demand curves}

Figures $3 \mathrm{~A}$ and $3 \mathrm{~B}$ represent the displacements of the supply curve to the left (Figure 3A) and demand to the right (Figure 3B) of the native and planted forest biomass, respectively, considering the price and quantity in 1998 and 2015.

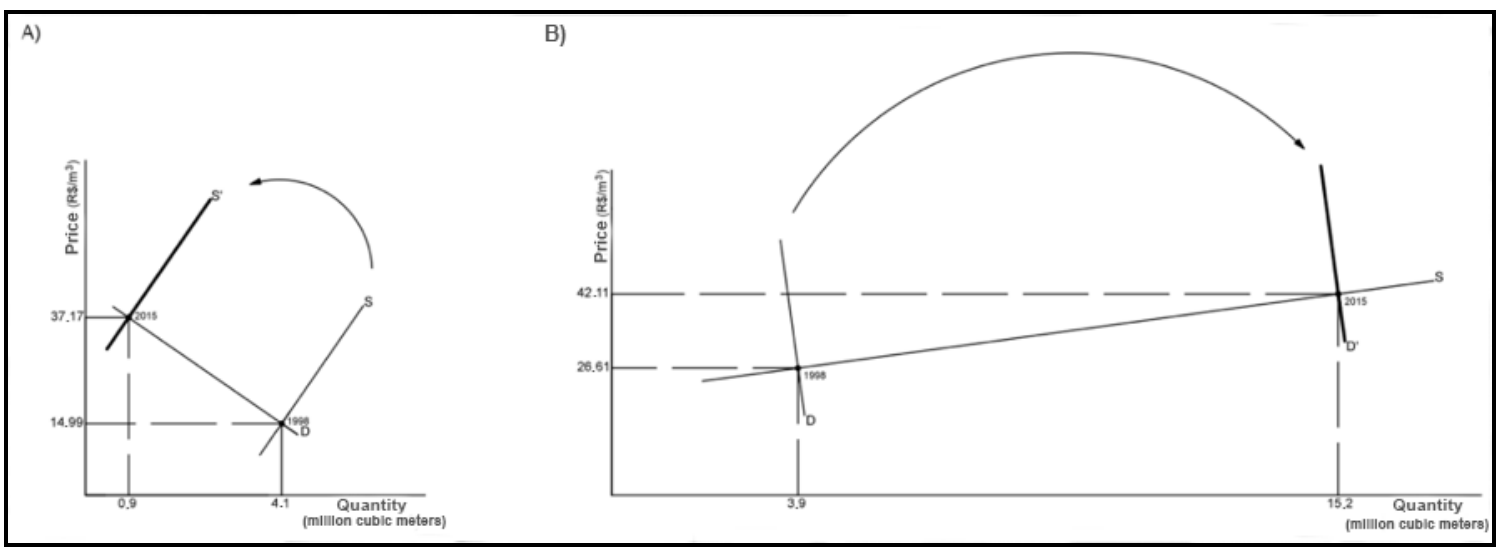

Figure 3. Displacement of the supply curve (S - S') of native forest biomass (A) and the demand (D - D') of planted forest biomass (B) from 1998 to 2015.

Figura 3. Deslocamento da curva de oferta $\left(S-S^{\prime}\right)$ da biomassa floresta nativa (A) e de demanda (D - D') da biomassa de floresta plantada (B) entre os anos de 1998 e 2015.

\section{DISCUSSION}

\section{Growth rates and behavior of the quantity and price curves of native and planted forest biomass}

According to Figure 1, between the years analyzed, there was a significant fall in the supply of native forest biomass in the state, even with the slight increase in the amount between 2003 and 2005, and 2011 and 2013. While in 1998 there was a supply of native forest biomass of 4.1 million $\mathrm{m}^{3}$, in 2015, the supply was 904 thousand $\mathrm{m}^{3}$. The linear regression model of the quantity curve pointed to a determination coefficient of 
$91.8 \%$, showing satisfactory adjustment of the model according to quantity observations collected over the analyzed years.

Regarding the price of native forest biomass, there was a decrease in quantity and an increase in the price of the product over the years, as shown by its curve in Figure 1. Between 2009 and 2010, there was a significant increase in the price, growing from $\mathrm{R} \$ 28.49 / \mathrm{m}^{3}$ to $\mathrm{R} \$ 47.67 / \mathrm{m}^{3}$, the highest price observed in the series. In comparison to the quantity curve, there was a slope in the same period, indicating that there was a reduction in the quantity offered, consequently the price increased. However, from 2011 to the end of the historical series, a reduction in the price of native biomass was observed, which shows a probable trend of price decreasing of products over the coming years. In 2015, the price of native forest biomass was $\mathrm{R} \$ 37.17 / \mathrm{m}^{3}$.

The linear regression model of the price curve indicated a determination coefficient of $74.14 \%$, showing satisfactory adjustment of the model according to the price observations over the analyzed years.

According to Figure 2, there was a significant growth trend in the supply of planted forest biomass in the state between the years analyzed, although a variation was observed between the years 2011 and 2014. While in 1998 there was a biomass supply of 3.8 million $\mathrm{m}^{3}$, in 2015 , the supply was more than 15 million $\mathrm{m}^{3}$. The linear regression model of the quantity curve showed a determination coefficient of $83.5 \%$, also showing satisfactory adjustment of the model according to the observations of the amount of biomass planted over the analyzed years.

The biomass quantity curve of planted forest suggests the presentation of three different behaviors at different time intervals: between 1998 and 2008, there was a gradual increase in the commercialized amount of planted biomass; between 2009 and 2011, there was a sudden increase; and between 2012 and 2015, it showed oscillations. In the last year, there was a tendency to increase quantity in the future, but there is no way to determine if this behavior occurred, since a decrease in quantity would also be possible for the following year.

As for the price of planted forest biomass, its growth was observed year after year, demonstrating how much this product has gotten appreciated over time. In 1998 , its price was $\mathrm{R} \$ 26.61 / \mathrm{m}^{3}$. In 2012 , it costed R\$ $52.02 / \mathrm{m}^{3}$, an increase of practically $100 \%$. As of 2013, prices have been falling until the last year of the series, but there is no way of saying that there will be a tendency for prices to fall in the coming years. In 2015, the price of planted forest biomass was $\mathrm{R} \$ 42.11 / \mathrm{m}^{3}$. The highest variable $\left(\mathrm{R} \$ 11.17 / \mathrm{m}^{3}\right)$ in 2001 and 2008 and the lowest $\left(\mathrm{R} \$ 25.88 / \mathrm{m}^{3}\right)$ in the years before and after each those mentioned were observed throughout the time series planted forest biomass prices for each of the years mentioned.

The linear regression model of the price curve showed a determination coefficient of $81.08 \%$, showing a satisfactory adjustment of the model according to the observations of the biomass price planted over the analyzed years.

\section{Substitute good determination}

According to the results in Table 2, the demand for biofuels, such as wood, for energy production was due to the replacement of biomass from native forests by planted forest biomass. In the period in which the result of $E_{p}$ was negative (2004 - 2009), a behavior of complementary product was verified, allowing to infer that, in that period, both products were important for the production of energy in Paraná.

\section{Behavior of supply and demand curves}

According to the results obtained and the one found by Almeida et al. (2009a), from the positive variation of the native biomass price combined with the negative variation of its quantity produced, the supply curve shifted to the left. This means that this behavior of price and production evolution has occurred to reduce the supply of the product in the market $(\downarrow S)$. Likewise, for the planted forest biomass, from the positive variation of the combined product price as the positive variation of its quantity produced, the demand curve shifted to the right, regardless of the displacement of the supply curve in the period. This means that this evolutionary behavior of price and production occurred to increase the demand of the product in the market ( $\uparrow \mathrm{D})$.

The equilibrium price for native forest biomass in the first year (1998) was $\mathrm{R} \$ 14.99 / \mathrm{m}^{3}$ for a marketed amount of 4.1 million $\mathrm{m}^{3}$. In the second year (2015), there was an increase in the equilibrium price of the product to $\mathrm{R} \$ 37.17 / \mathrm{m}^{3}$ for a marketed quantity of 0.9 million $\mathrm{m}^{3}$. For planted biomass, the equilibrium price in the first year (1998) was R \$26.61/ $\mathrm{m}^{3}$ for a marketed amount of 3.9 million $\mathrm{m}^{3}$, while in the second (2015) there was an increase in the equilibrium price of the product to $\mathrm{R} \$ 42.11 / \mathrm{m}^{3}$ for a marketed quantity of 15.2 million $\mathrm{m}^{3}$.

According to Rubinfeld and Pyndick (2011), the supply of a given product is associated with several factors, such as market price, factor prices and inputs (labor, raw materials, etc.), price of substitute products, technology available for production, as well as factors of economic, legal, environmental, cultural, etc. As for the reduction in the supply of native forest biomass in the state, some aspects can be observed, such as the implementation of Federal Law 11.428 of December 22, 2006, which deals with the use and protection of the

FLORESTA, Curitiba, PR, v. 49, n. 1, p. 011-020, jan/mar. 2019 
native vegetation of the Atlantic Forest Biome. Popularly known as the "Law of the Atlantic Forest", it establishes the conditions for the cutting and suppression of forest vegetation in different stages of succession, requiring the approval of the competent environmental agency in practically all situations.

For example, article 23 of this law deals with the conditions for cutting or suppression authorization of secondary vegetation in the middle stage of regeneration (only two): exceptionally, for works of social interest, scientific research and preservationist practices; and for the small rural producers and traditional populations for the exercise of subsistence activities, with agricultural, livestock and silvicultural use. In some situations, it is also necessary to carry out environmental compensations by replenishing native species in areas located in the same watershed, or, if possible, in the same micro-watershed (BRASIL, 2006).

However, even with the implementation of this instrument, which would, in theory, protect the native forests of the Atlantic Forest, predatory action is not inhibited, since certain pieces of legislation can become "traps" according to Vajarbedian (2010). Article 9 of the Law, for example, deals with the authorization independence of the competent bodies for the eventual exploitation (without direct and indirect commercial purpose) of native species for consumption in the properties or possessions of traditional populations or small rural producers. However, the decree regulating the Law (decree 6.660/2008), in the first paragraph of article 2, considers, within this holding, firewood for domestic use, allowing a withdrawal of up to 15 cubic meters per year for ownership or possession (BRASIL, 2006; BRASIL, 2008).

Despite the lack of accurate information, the illegal removal of wood from native forests for the manufacture of products such as firewood, for example, may be one of the probable reasons for the existence of a native biomass market in Paraná, as mentioned by Tetto et al. (2008). Particularly among traditional communities and small producers, the demand for firewood generally comes from natural areas of the Atlantic Forest. Therefore, in the absence of supervision by the competent bodies, the withdrawal of native species may be indiscriminate, hindering the maintenance of the biome.

Although the application of this legal instrument may indicate a probable response in the reduction of native forest biomass supply, it is recommended to carry out studies on the impacts of public policies as a way of pointing out the causes of this reduction with greater security.

As an alternative for the biomass supply of natural forests, there was an increase in the biomass supply from forest plantations of genera such as Pinus sp., Eucalyptus sp., Mimosa (Bracatinga), among others, in the Paraná market (CARPANEZZI, 2007). According to Vitale and Miranda (2010), the choice to produce pine and eucalyptus trees as raw materials instead of those obtained through native forest trees occurs because these species present high productivity in Brazilian soil and a great variety of products that use their wood.

In the state of Paraná, reforestation agents are pulp and paper companies, companies producing solid wood (sawing and panels), firewood, yerba mate, and small and medium-sized producers. According to Bacha and Barros (2004), these are also the main reforestation agents in the national sphere. According to the spatial distribution of the regions, used by the State Secretariat of Agriculture and Supply (SEAB), the Center-South region is the one that is most prominent in the forest sector of planted forests (PARANÁ, 2015).

The state of Paraná added in 2015 an area of 1,066,479 hectares of pine and eucalyptus forests, which represented approximately $5.4 \%$ of the total area of the state. There were 653,566 ha of pine $(65.8 \%$ of the total planted area), 340,315 ha of eucalyptus (34.2\% of the total planted area) and 72,598 ha of cleared or newly planted area. Between the total planted, the variation was $25.7 \%$ from the year 2010 to 2015 (EISFELD, NASCIMENTO, 2015, IBÁ, 2016). During this period, the annual growth rate was $2.96 \%$ per year.

There are also some specific policy measures in the national sector, such as the New Forest Code. According to Dorneles (2011), they end up influencing the forestry sector of Paraná, creating projects such as the Strategic Planning of the Forestry Sector, the Paraná Forestry Parliamentary Front, the family agriculture incentive programs and the new Low Carbon Agriculture (LCA).

Biomass is one of the main sources of energy used in Paraná. Given the vocation of the state for grain production, it is imperative that there is a constant source of energy that does not originate from natural forests, considering the context of Law 11.428/2006. Therefore, the biomass of planted forests (in this case, called energy forests) is of fundamental importance for the attention of the agricultural sector of Paraná.

\section{CONCLUSION}

- The analysis indicated that the increase in price of native forest biomass between 1998 and 2015 occurred mainly due to factors related to the decrease in the supply of the product in the market, suggesting the relation with the legal aspects as a possible cause that concern the protection of the Atlantic Forest biome.

- Throughout the temporal evolution analyzed in this study, it was concluded that the consumption of biofuels produced from native forest wood was decreasing. On the other hand, the biomass consumption of planted 
forests increased due to legal protection aspects of the Atlantic Forest, increased investments in pine and eucalyptus forests in the state of Paraná, political measures and rural incentive programs.

- By dividing the time series into shorter periods, it was possible to verify that the biomass of planted forest replaced native forest biomass in the state of Paraná in the initial and final years of the historical series analyzed, but were complementary between years 2004 and 2009.

- The increase of price inforest biomass planted between 1998 and 2015 was mainly due to factors related to the growth of the domestic demand for energy production, as a way of serving the various sectors of the economy in the state of Paraná, allowing the substitution of native forest biomass for forest crop biomass.

\section{REFERENCES}

AlMEIDA, A. N.; SilvA, J. C. G.L.; ANGelO, H.; BITTEnCOURT, A. M.; NUNEZ A. E. C. Mercado Paranaense de madeira em tora procedente de silvicultura entre 1999 e 2005 . Floresta, Curitiba, v. 39, n. 4, p. 869-875, 2008.

AlMEIDA, A. N.; BITTENCOURT, A. M.; SANTOS, A. J.; EISFELD, C. L.; SOUZA, V. S. Evolução da produção e preço dos principais produtos florestais não madeireiros extrativos do Brasil. Revista Cerne, Lavras, v. 15 , n. 3, p. 282 - 287, 2009a.

AlMEIDA, A. N.; ANGElO, H.; SILVA, J. C. G. L.; NUÑEZ, B. E. C. Análise econométrica do mercado de madeira em tora para o processamento mecânico no Estado do Paraná. Scientia Forestalis, Lavras, v. 37, n. 84, p. 377 - 386, 2009b.

BACHA, C. J. C.; BARROS, A. L. M. Reflorestamento no Brasil: Evolução recente e perspectivas para o futuro. Scientia Forestalis/Forest Sciences, n. 66, p. 191-203. 2004.

BRAND, M. A.; STÄHELIN, T. S. F.; FERREIRA, J. C.; NEVES, M. D. Produção de biomassa para geração de energia em povoamentos de Pinus taeda L. com diferentes idades. Revista Árvore, Viçosa, v. 38, n.2, p. 353360, 2014.

BRASIL. Lei $\mathrm{n}^{\circ} 11.428$, de 22 de dezembro de 2006. Dispõe sobre a utilização e proteção da vegetação nativa do Bioma Mata Atlântica, e dá outras providências. Diário Oficial da União, Brasília, DF, vinte e seis de dezembro de 2006. Disponível em < http://www.planalto.gov.br/ccivil_03/_ato2004-2006/2006/lei/111428.htm> Acesso em: $21 \mathrm{dez} 2016$.

BRASIL. Decreto $\mathrm{n}^{\circ}$ 6.660, de 21 de dezembro de 2008. Regulamenta dispositivos da Lei no 11.428 , de 22 de dezembro de 2006, que dispõe sobre a utilização e proteção da vegetação nativa do Bioma Mata Atlântica. Diário Oficial da União, Brasília, DF, vinte quatro de novembro de 2008. Disponível em < http://www.planalto.gov.br/ccivil_03/_ato2007-2010/2008/decreto/d6660.htm> Acesso em: 22 dez 2016.

CARPANEZZI, O. T. B. Espécies vegetais exóticas no Parque Estadual de Vila Velha: subsídios para controle e erradiação. 2007. 49 f. Monografia (Especialização em Análise Ambiental) - Universidade Federal do Paraná, Curitiba.

COMPANHIA PARANAENSE DE ENERGIA - COPEL. Balanço Energético e Consumo final por fonte. Disponível em: < http://www.copel.com/hpcopel/root//mapaSite.jsp>. Acesso em: 23/12/2016.

DORNELES, R. C. Análise da conjuntura agropecuária safra 2011/2012: produtos florestais. Secretaria da Agricultura e do Abastecimento. DERAL. Curitiba, 2011, 16 p.

EISFELD, R. L.; NASCIMENTO, F. A. F. Mapeamento dos plantios florestais do Estado do Paraná: Pinus e Eucalyptus. Curitiba: Instituto de Florestas do Paraná, 2015, 76 p.

EMPRESA DE PESQUISA ENERGÉTICA - EPE (Brasil). Balanço Energético Nacional (BEN) 2016: Ano Base 2015. Rio de Janeiro: EPE, 2016.

GUJARATI, D. N.; PORTER, D. C. Econometria Básica. 5 ed. Porto Alegre: AMGH, 2011.

IBÁ. Indústria Brasileira de Árvores. Indústria Brasileira de Árvores. Ano base 2015. 2016.

INTERNATIONAL ENERGY AGENCY - IEA. IEA Energy Atlas. Disponível em: < http://www.iea.org/statistics/ieaenergyatlas/> Acesso em: 13/03/2015.

FLORESTA, Curitiba, PR, v. 49, n. 1, p. 011-020, jan/mar. 2019

Santos. T. M. S et.al.

ISSN eletrônico 1982-4688 
INSTITUTO BRASILEIRO DE GEOGRAFIA E ESTATÍSTICA - IBGE. Produção da Extração Vegetal e Silvicultura. Disponível em: <http://www2.sidra.ibge.gov.br/bda/pesquisas/pevs/default.asp?o=31\&i=P>. Acesso em: 26/02/2016.

MANKIW, N.G. Introdução à economia. São Paulo: Cengage Learning, 2015.

MOREIRA, J. M. M. P.; SIMIONI, F. J.; SANTANA, L. F. Impacto do regime de manejo na rentabilidade da produção de lenha de eucalipto na região de Itapeva-SP, sob condições de risco. SOBER - Sociedade Brasileira de Economia, Administração e Sociologia Rural, in: 54 Congresso da Sociedade Brasileira de Economia, Administração e Sociologia Rural, Maceió, 2016.

PARANÁ. SETI - Secretaria de Estado da Ciência, Tecnologia e Ensino Superior. Oferta e demanda de madeira para fins industriais no Estado do Paraná. Curitiba, 2007.

SEAB - Secretaria da Agricultura e do Abastecimento. DERAL - Departamento de Economia Rural. Valor bruto da produção rural paranaense. Curitiba, 2015.

PINDYCK, R.; RUBINFELD, D. Microeconomia. São Paulo: Prentice Hall, 2011.

TABACHNICK, B.; FIDELL, L.; OSTERLIND, S. Using multivariate statistics. Boston: Ally \& Bacon. 2001. $966 \mathrm{p}$.

TETTO, A. F.; HOEFLICH, V. A.; RUCKER, N. G. de A.; SILVA, D. A. T.; BORGES, J. L. Histórico dos Preços e da Produção de Lenha e de Carvão Vegetal, no Estado do Paraná, entre 1997 e 2007. In Congresso da Sociedade Brasileira de Economia, Administração e Sociologia Rural (SOBER), XLVI, Rio Branco (CD), 2008.

VARJABEDIAN, R. Lei da Mata Atlântica: retrocesso ambiental. Estudos Avançados, São Paulo, v. 24, n. 68, p. 147-160, 2010.

VITALE, V.; MIRANDA, G. DE M. Análise comparativa da viabilidade econômica de plantios de Pinus taeda e Eucalyptus dunnii na região Centro-sul do Paraná. Revista Floresta, Curitiba, v. 40, n. 3, p. 469-476, 2010. 